\title{
FEN BIILGISII ÖĞRETMEN ADAYLARININ ARGÜMANTASYON TABANLI ÖĞRENME YAKLAŞIMINA YÖNELİK GÖRÜŞLERİ
}

\author{
VIEW'S OF PRE-SERVICE SCIENCE TEACHERS ABOUT ARGUMENTATION BASED \\ LEARNING APPROACH
}

DOI:10.17755/esosder.48760

\author{
Hilal AKTAMIŞ ${ }^{1}$ \\ Ayşe Ceren ATMACA ${ }^{2}$
}

\section{$\ddot{O} z$}

$\mathrm{Bu}$ çalışmanın amacı fen bilgisi öğretmen adaylarının argümantasyon tabanlı öğrenme yaklaşımına ilişkin görüşlerinin tespit edilmesidir. Bu çalışma Ege Bölgesindeki bir devlet üniversitesinin eğitim fakültesinde Fen Bilgisi öğretmenliği bölümünde öğrenim gören üçüncü sınıf öğrencileri ile gerçekleştirilmiştir. Araştırmanın katılımcı grubu 48 kişiden oluşmaktadır. Katılımcı grupta yer alan 47 öğrencinin 35'i kız (\%75), 12'si erkek (\%25) öğrencilerden oluşmaktadır. Katılımcı grup oluşturulurken ölçüt örnekleme yöntemi kullanılmıştır. Araştırmanın yürütüldüğü süreçte Fen Öğretimi Laboratuvar Uygulamaları 1 dersini alan fen bilgisi öğretmen adayları çalışmanın katılımcıları olarak belirlenmiştir. Çalışmada veri toplama aracı olarak araştırmacılar tarafından hazırlanan açık uçlu soruların bulunduğu argümantasyon tabanlı öğrenme yaklaşımı görüşler anketi kullanılmıştır. Veri toplama aracı olarak oluşturulan ankette 5 adet açık uçlu soru bulunmaktadır. Verilerin analizi argümantasyon tabanlı yaklaşımın öğretmen adaylarında kalıcı ve etkili öğrenmeler oluşturduğu, öğretmen adaylarının fikirlerini rahatça ifade etmesi için uygun ortamların oluştuğu, öğretmen adaylarını araştırma ve sorgulamaya teşvik ettiğini fakat zaman sıkıntısı yaşadıklarını ortaya koymuştur.

Anahtar Kelimeler: fen eğitimi, argümantasyon tabanlı öğrenme yaklaşımı

\begin{abstract}
The aim of this study is to determine preservice science teachers' views about argumentation based learning aproach. This study was carried out with a third-grade students studying in science education of a university in Aegean region. Participant group of the research comprises fourty eight preservice science teachers. Thirty six pre-service science teachers who participated in this study are female $(\% 75)$ and twelve of them is male $(\% 25)$. Participant pre-service science teachers were selected among the ones who took the course "Science Education Laboratory Practice 1" with criterion sampling method throughout the research. In this study, argumentation based learning approach survey was used as data gathering tool which include open ended guestions developed by researcher. Survey was created as data gathering tool consist of five open ended questions. The findings revealed that argumentation based learning approach provided pre-service science teachers with effective and long-lasting learning, this approach created favorable learning situations for pre service science teachers to express themselves easily and that this approach encouraged pre-service science teachers to investigate and inquiry but still they face problems related to time management.
\end{abstract}

Keywords: science education, argumentation based learning approach

\footnotetext{
${ }^{1}$ Doç.Dr., Adnan Menderes Üniversitesi, Eğitim Fakültesi, hilalaktamis@hotmail.com

${ }^{2}$ Arş.Gör., Adnan Menderes Üniversitesi, Eğitim Fakültesi, ceren eylul24@hotmail.com
} 


\section{GíRiș}

Bilimsel bilginin ve teknolojik gelişmelerin günden güne arttığ günümüzde bu hızlı ilerleyişe eşlik edebilmek ancak kaliteli fen bilimleri eğitimi ile mümkün olmaktadır. $\mathrm{Bu}$ nedenle toplumlar fen bilimleri ögretim programlarını yeniliklere açık durumda tutabilmek için sürekli güncellemektedirler. Son yıllardaki fen bilimleri öğretim programları incelendiğinde öğrenciyi merkeze aldıkları görülmektedir. Eski programlardaki ağır içerik kaldırılarak yerine öğrencinin sorgulamasına olanak veren içerikler düzenlenmiştir. Güncellenen programlar ile bilimsel bilgiyi ezberleyen değil, bilgi üreten, öğrendiklerini günlük hayatında uygulayabilen, araştıran, sorgulayan bireyler yetiştirilmesi amaçlanmaktadır. Öğretim programlarındaki yeniliklere paralel olarak sınıflarda kullanılan öğretim yöntem ve teknikleri de değişmiştir. Öğretim ortamlarında eskiden kullanılan geleneksel yöntemler yerine, öğrenci merkezli yöntemler kullanılmaya başlanmıştır. (Kabataş Memiş, 2014).

İçinde bulunduğumuz bilgi çağında yeniliklere açık olan, fen ve teknoloji alanındaki gelişmeleri takip edebilen, öğrendikleri bilgileri günlük hayatla bağdaştırarak, karar verirken ve problem çözerken kullanabilen, fikir üretebilen, çözüm üretebilen kısacası bilimsel okuryazar bireylere ihtiyaç vardır (Ulu ve Bayram, 2015). Fen eğitimi bireylere eleştirel düşünmeyi, tartışmayı, sorgulamayı öğretir. Öğrendikleri bilgileri, karşılaştıkları durumları sorgulamayan bireyler geçmişten gelen, bilimsel dayanağı olmayan bilgilerin ve inanışların gölgesinde kalır. Böylece duyduğunu, gördüğünü koşulsuz kabul eden bireyler yetişir. Sorgulamayan, araştırmayan, merak etmeyen bireylerden oluşan toplumlar ilerleme kaydedemez, çağın gereksinimlerini karşılayamaz ve zamanla her yönden başka toplumlara bağlı hale gelir. Bu duruma ancak fen derslerini sadece eğitim hayatı boyunca aldığı bir ders olmaktan çıkarıp, hayatının her aşamasında Fen'i kullanan ve tartışan bireyler yetiştirerek engel olunabilir. Bu sebeple fen eğitiminin verilmeye başlandığ 1 kademelerde ki öğrencilere fen bilimleri dersinin kitaplar ve formüllerden ibaret olmadığı ezber ile değil bizzat yaparak yaşayarak öğrenilmesi gereken bilgiler bütünü olduğu farkındalığı kazandırılarak eğitim verilmelidir (Kurbağ Zengin, Keçeci ve Kırılmazkaya, 2012). Bunu sağlamak için eğitim alanında geçmişten günümüze öğretim programlarındaki eksiklik veya yanlışlıklar göz önüne alınarak birçok kuram denenmiştir. Bu kuramların içinde son zamanlarda en çok benimsenen kuram yapılandırmacı öğrenme kuramıdır. Yapılandırmacı öğrenme kuramı öğrenciyi merkeze alan, aktif öğrenme sağlayan, öğrencilerin yeni bilgileri mevcut bilgileri üzerine yapılandırdıkları kuramdır (Günel, Kıngır ve Geban, 2012).

Yapılandırmacı öğrenme kuramı temelli yaklaşımlardan biri de argümantasyon tabanlı öğrenme yaklaşımıdır. Argümantasyon temelli öğrenme yaklaşımında öğrenciler bilgiye ulaşırken sorular sorar, iddialar oluşturur ve oluşturdukları bu iddiaları kanıtlarla desteklerler. Öğrenciler iddialarını oluştururken ve desteklerken fikirlerini grup veya sınıf arkadaşları ile paylaştıkları için sosyal ortamda aktif öğrenme ile bilgiye ulaşırlar (Erduran, Simon ve Osborne, 2004).

Argüman ve argümantasyon kavramları arasındaki fark zaman zaman bireyler tarafından karıştırılmaktadır. Literatüre bakıldığında argüman ve argümantasyon kavramlarının zaman içinde farklı araştırmacılar tarafindan tanımlandığı görülmektedir (Üstünkaya ve Savran Gencer, 2012). Van Eemeren ve Grootendorst (1996)' ya göre argüman; bilginin ispatlanmasıdır. Araştırmacılar argümanı veriler ve iddialar aracılı̆̆ıyla bilginin doğruluğunun ispatlanması olarak tanımlamaktadırlar. Kuhn (2009)'a göre argüman bir durum için veya duruma karşıt nedenler oluşturmaktır.

Argümantasyon, basit tartışmalar değildir. Argümantasyon, fikirler öne sürülen bu fikirleri destekleyecek bilgileri sunan, oluşturulan iddiaların ve verilerin arasındaki bağlantıyı 
açıklayan kısacası bilimsel bilginin oluşum sürecini gösteren ve öğrencileri bizzat bu sürece dahil eden bir yaklaşımdır (Aymen Peker, Apaydın ve Taş, 2012; Aydın ve Fitnat, 2014).

Jimenez-Alexander ve diğerleri (2000) argümantasyonun tanımını mevcut problemleri giderme çabası olarak yapmıştır. Kaya ve Kılıç (2008)'e göre argümantasyon karşıt durumlar arasındaki bağlantıyı belirtmek için yapılan eylemdir. Aldağ (2005) ise argümantasyonu farklı veya aynı konumlardaki insanların veya toplulukların karar vermek, olguyu açıklamak veya anlamak, problem çözmek için gerçekleştirdikleri eylemlerin bütünü ve bu eylemler sonucu elde edilen ürün olarak tanımlamaktadır.

Argümantasyon tabanlı öğrenme yaklaşımı ile ilgili araştırmalara bakıldığında, bu yaklaşımın öğrencilerin bilgiye daha kolay ulaşmasında, fen kavramları ile ilgili olan yanlış anlamalarının ortaya çıkarılmasında, öğrencilere eleştirel düşünme becerisinin kazandırılmasında, birbirleri ile olan iletişimlerinin geliştirilmesinde katkı sağladığ görülmüştür. Yapılan araştırmalar argümantasyon tabanlı öğrenme yaklaşımının sınıflarda kullanılmasının öğrencilerin kendi düşüncelerini bilimsel ifadeler kullanarak belirtme ve yazma eylemlerini geliştirdiğini ortaya koymaktadır (Tümay ve Köseoğulu, 2011; Keçeci ve ark., 2011). Öğrencilere bilimsel düşünme becerisi kazandıran argümantasyon tabanlı bilim öğrenme yaklaşımının öğretim ortamlarında programlara dahil edilmesiyle fen eğitiminin en temel amacı olan bilimsel okur yazar bireyler yetiştirmek olgusuna ulaş1labileceği düşünülmektedir (Köseoğlu, Tümay ve Budak, 2008).

Argümantasyon tabanlı fen eğitimi ile öğrenciler kendilerinde daha önceden var olan modelleri sorgular, kendi modellerini arkadaşlarınınki ile karşılaştırır, kendi modellerini savunabilmek için bilimsel yöntem basamaklarına dayanarak iddia, neden ve delil belirtirler. $\mathrm{Bu}$ sayede var olan modellerini desteklemeleri ve onaylanmayanların elenmesi sonucunda kavramlarda farklılık oluşur (Ceylan,2012). Fen bilimleri derslerinde argümantasyon tabanlı etkinlikler kullanarak bilimsel tartışma ortamları oluşturulabilir. Yapılacak olan bu etkinliklerle öğrenciler argümantasyon ile ilgili olumlu düşüncelere sahip olabilirler (Aydın ve Fitnat, 2014).

Argümantasyon tabanlı öğrenme yaklaşımının fen eğitimindeki önemini açıkça gösteren çalışmaların yanı sıra argümantasyon tabanlı öğrenme yaklaşımının sınıf ortamında kullanılması sırasında ortaya çıkan zorlukları ortaya koyan çalışmalar da vardır. Yapılan araştırmalar argümantasyon tabanlı öğrenme yaklaşımının öğretim ortamlarında uygulandığı esnada öğrencilere bilimsel düşünme, fikirlerini rahatça ifade etme gibi süreçlerde yeterince firsat verilmediği, öğrenci merkezli olmaktan çıkıp daha çok öğretmen merkezli bir uygulamaya dönüştüğünü ve öğretim ortamlarında öğrencilerin fikirlerinden çok öğretmenlerin yönlendirmeleri sonucu ulaşılan sonuçlar ile bilgilerin oluşturulduğu tespit etmiştir. Yapılan araştırmalarda argümantasyon tabanlı öğrenme yaklaşımının sınıflarda uygulaması için gerekli olan işbirlikli öğrenme ortamlarının oluşmadığı, öğrencilerin kendi aralarında, grup içinde argümantasyon tabanlı yaklaşımın verimli şekilde uygulanması için gerekli olan iletişim becerilerini kazanamadığı bu sebepten dolayı da ne kendi fikirlerini ne de grup içindeki diğer arkadaşlarının fikirlerini etkili şekilde değerlendiremediği bunun sonucunda da eleştirel düşünme ve fikirlerini nesnel olarak değerlendirip sonuca ulaşma becerilerinde yetersiz kaldıkları görülmüştür. Araştırmalardan elde edilen bir diğer sonuç da öğretim ortamlarında bu yaklaşımı uygulayacak olan öğretmenlerin argümantasyon tabanlı yaklaşımın doğası, özellikleri ve uygulama süreci hakkında yeterli bilgiye sahip olmadıkları ve bu durumun bir sonucu olarak argümantasyon tabanlı yaklaşımın uygulama sürecinde yetersiz kalındığıdır (Erduran \& Jimenez - Aleixandre, 2007; Driver, Newton \& Osborne, 2000). 
Fen öğretiminde argümantasyon tabanlı bilim öğrenme yaklaşımının uygulandığ 1 öğrenme ortamlarında karşılaşılan sorunlar açıkça gösteriyor ki argümantasyon tabanlı öğrenme yaklaşımının etkili şekilde uygulanması için önce öğretmenlerin argümantasyon tabanlı öğrenme yaklaşımının uygulama bilgisine sahip olması gerekmektedir. Argümantasyon tabanlı öğrenme yaklaşımını uygulayacak olan öğretmenlerin yaklaşımın doğasına, özelliklerine ve uygulama sürecine hakim olmaları gerekmektedir.

\section{Araştırmanın Amacı}

Bu çalışmanın amacı fen bilgisi öğretmen adaylarının argümantasyon tabanlı öğrenme yaklaşımına ilişkin görüşlerini tespit etmektir.

\section{Araştırma Problemleri}

Fen bilgisi öğretmen adaylarının argümantasyon tabanlı öğrenme yaklaşımına yönelik görüşleri nelerdir?

Araştırmanın alt problemleri :

$\checkmark$ Fen bilgisi öğretmen adaylarına göre argümantasyon tabanlı öğrenme yaklaşımının avantajları/dezavantajları nelerdir?

$\checkmark$ Fen bilgisi öğretmen adayları argümantasyon tabanlı yaklaşımın etkililiğine inanıyor mu?

$\checkmark$ Fen bilgisi öğretmen adayları gel1.ecekte öğretmenlik yaptıkları öğretim kurumlarında derslerini argümantasyon tabanlı yaklaşım temel alınarak hazırlanan etkinlik kağıtları kullanarak işlemeyi düşünürler mi?

\section{Araştırmanın Önemi}

Araştırma sonucunda elde edilecek bulgular ile öğretmen adaylarının argümantasyon tabanlı öğrenme yaklaşımının etkililiği ve öğretim ortamlarındaki uygulama süreçleri hakkındaki görüşleri değerlendirilerek bu argümantasyon tabanlı yaklaşımın uygulama esnasında ki sınırlılıklarının giderilmesinde ve yaklaşımın öğrenme ortamlarında daha verimli şekilde uygulanması için yapılacak araştırmalara yardımcı olacaktır.

\section{YÖNTEM}

Araştırma nitel bir çalışmadır. Araştırmanın deseni ise nitel araştırma desenlerinden bir durumun derinlemesine incelendiği durum çalışmasıdır (Yıldırım ve Şimşek, 2011).

\section{Katılımcı Grup}

Bu çalışma Ege Bölgesindeki bir devlet üniversitesinin eğitim fakültesinde Fen Bilgisi öğretmenliği bölümünde öğrenim gören üçüncü sınıf öğrencileri üzerinde gerçekleştirilmiştir. Araştırmanın katılımcı grubu 48 kişiden oluşmaktadır. Katılımcı grupta yer alan 47 öğrencinin 35'i kı (\%75), 12'si erkek (\%25) öğrencilerden oluşmaktadır. Örneklem oluşturulurken ölçüt örnekleme yöntemi kullanılmıştır. Araştırmanın yürütüldüğü süreçte Fen Öğretimi Laboratuvar Uygulamaları 1 dersini alan fen bilgisi öğretmen adayları çalışmanın katılımcı grubu olarak belirlenmiştir. Katılımcı olarak belirlenen grupta Fen Öğretimi Laboratuvar Uygulamaları 1 dersi argümantasyon tabanlı öğrenme yaklaşımı temel alınarak işlenmektedir. Ders iki saat teorik ve iki saat uygulama olarak işlenmektedir. Teorik derslerde argümantasyonun ne olduğu, teknikleri, derslerde nasıl kullanılacağı ve değerlendirileceği 
işlenirken, uygulamalı derslerde her hafta argümantasyon tekniklerinden birine yönelik hazırlanan etkinlik yapraklarının uygulaması yapılmıştır.

\section{Veri Toplama Aracı}

Çalışmada veri toplama aracı olarak araştırmacı tarafından hazırlanan açık uçlu soruların bulunduğu argümantasyon tabanlı öğrenme yaklaşımı görüşler anketi kullanılmıştır. Veri toplama aracı olarak oluşturulan ankette 5 adet açık uçlu soru bulunmaktadır. Veri toplama aracı olarak kullanılan anketin geçerliliği argümantasyon konusunda uzman bir öğretim üyesi ve 4 yüksek lisans öğrencisinin görüşü alınarak sağlanmıştır. Uzmanlar tarafından incelenen anket sorularının anlaşılabilirliği ve yeterliliği konusunda fikir birliği sağlanmıştır.

\section{Uygulama}

Araştırma 2015-2016 güz döneminde Ege bölgesindeki bir devlet üniversitesinin eğitim fakültesinde fen bilgisi öğretmenliği bölümünde öğrenim gören 47 üçüncü sınıf öğrencisi ile gerçekleştirilmiştir. Veri toplama aracı olarak kullanılan ve araştırmacı tarafından oluşturulan içinde açık uçlu soruların yer aldığı anket Fen Öğretimi Laboratuvar Uygulamaları 1 dersini alan 48 ögrrenciye dönemin son dersinde tek seferde uygulanmıştır.

\section{Verilerin Analizi}

Araştırmada öğretmen adaylarının argümantasyon tabanlı öğrenme yaklaşımı anketinin sorularına verdikleri cevapların analizinde içerik analizi yöntemi kullanılmıştır. Çalışmada veri toplama aracı olarak kullanılan argümantasyon tabanlı öğrenme yaklaşımı görüşler anketinin içerdiği beş açık uçlu sorunun analizi sonucu beş tema belirlenmiştir. Belirlenen temalar ve temalara ilişkin sorular aşağıdaki gibidir.

Tema 1: Avantaj

Soru 1: Sizce argümantasyon tabanlı öğrenme yaklaşımının avantajları nelerdir?

Tema 2: Dezavantaj

Soru 2: Sizce argümantasyon tabanlı öğrenme yaklaşımının dezavantajları nelerdir?

Tema 3: Memnuniyet

Soru 3: Derslerinizin argümantasyona dayalı etkinliklerle işlenmesinden ;

a) memnun musunuz? Nedenlerini belirtiniz

b) memnun değil misiniz? Nedenlerini belirtiniz

Tema 4: Etkililik

Soru 4: Argümantasyon tabanlı öğrenme yaklaşımının etkililiğine;

a) inaniyor musunuz? Nedenlerini belirtiniz.

b) Inanmiyor musunuz? Nedenlerini belirtiniz.

Tema 5: Tercih Etme

Soru 5: Ders sürecinde gerçekleştirilen bu uygulamadan sonra ileride öğretmenlik yaptığınızda derslerinizi argümantasyon tabanlı öğrenme yaklaşımına göre etkinlikler kullanarak işlemeyi düşünür müsünüz? Nedenlerini belirtiniz.

Araştırmada öğretmen adaylarının anket sorularını tarafsız bir şekilde cevapladıkları varsayılmıştır. Araştırma Ege bölgesinde bir devlet üniversitesinde öğrenim gören 47 
öğretmen adayı ile sınırlıdır. Katılımcı grup olarak 48 öğretmen adayı belirlenmiş fakat 1 öğretmen adayından geri dönüş olmamıştır.

\section{BULGULAR}

Araştırmada öğretmen adaylarına ait alıntılar hiçbir değişiklik yapılmadan verilmiştir. Çalışmada öğretmen adaylarının anket sorularına verdikleri cevaplar her soru için dahil olduğu tema ve kodlar ile aşağıda sunulmuştur.

\section{1) Sizce argümantasyon tabanlı öğrenme yaklaşımının avantajları nelerdir?}

Fen bilgisi öğretmen adayları ile gerçekleştirilen bu çalışmada öğretmen adaylarına argümantasyon tabanlı öğrenme yaklaşımının avantajları sorulmuştu. Öğretmen adayları yöntemin avantajlarını bilimsel okur yazarlık ve fen okuryazarlığını geliştirdiği, karar verme, problem çözme, akıl yürütme ve eleştirel düşünme becerisini kazandırdığı, kalıcı ve etkili öğrenme sağladığı, bilimsel bilginin yapılandırılmasını öğrettiği ve bireyler arasında sosyal etkileşimi arttırdığı şeklinde belirtmişlerdir. Bazı görüşler şöyledir:

Öğretmen Adayl 4; 'Argümantasyon tabanlı öğrenme fen okuryazarlık becerilerini geliştirir. Akll yürütme, eleştirel düşünme, karar verme yetisini arttırır.'

Öğretmen Adayı 5; ' Ö̆grencilere sosyal bir ortam sağlar. Fen okuryazarlık becerisini geliştirir. Akll yürütmeyi eleştirel düşünmeyi geliştirir.'

Öğretmen Adayı 1; ' Bilimsel okuryazarlı becerisini kazanmaya, bilimsel bilginin nasıl yapılandırıldı̆̆ını ve değerlendirildiğini anlamalarına, sosyal becerilerini geliştirmelerine destek verir.'

Öğretmen Adayı 19; 'Etkili, kalıcı ögrenme să̆lar.'

Öğretmen Adayı 47; 'Problem çözme becerisini geliştirir.'

\section{2) Sizce argümantasyon tabanlı öğrenme yaklaşımının dezavantajları nelerdir?}

Öğretmen adaylarına argümantasyon tabanlı öğrenme yaklaşımının dezavantajları sorulmuştu. Öğretmen adayları yöntemin dezavantajlarını uygulamanın çok zaman aldığı, kalabalık sınıf ortamlarında ve araştırma imkanının kısıtlı olduğu durumlarda uygulamanın zor olduğu, grup çalışmalarında bireyler arası uyumsuzluk yaşandığı, bireysel farklılıklara uygun olmadığı şeklinde ifade etmişlerdir.

Öğretmen Adayı 34; ' Grup şeklinde yapıldı̆̆ında kişiler arası birbirini anlamama ve anlatamamadan dolayı sorunlar çıkması.'

Öğretmen Adayı 37: ' Ĕger tartışma ortamı yaparken suskun veya çekinik öğrenciler derse katılmaz:'

Öğretmen Adayl 42; ' Yeterli araştırma imkanlarl olmadĭ̆ zaman bu öğrenme yaklaşımı dezavantaja dönüşür. Zaman kısitlılı̆̆ı dezavantajları arasında gösterilebilir.'

Öğretmen Adayı 41; 'Zaman kısıtlı olabilir. Imkanlar kısıtlı olabilir. Sinıf kalabalık olabilir.'

Öğretmen Adayı 4; 'Argümantasyon tabanlı ögrenme, kendini ifade etme zorluğu çeken biri için zor bir yaklaşım olabilir. Grup çalışması yapılırken anlaşmazlıklar yaşanabilir.'

3) Derslerinizin argümantasyona dayalı etkinliklerle işlenmesinden; 
a) Memnun musunuz? Nedenlerini belirtiniz

b) Memnun değil misiniz? Nedenlerini belirtiniz.

Öğretmen adaylarına derslerinin argümantasyona dayalı etkinliklerle işlenmesinden memnun olup olmadıkları sorulmuş ve 47 ögretmen adayından 46'sı memnun olduğunu belirtmiştir. Öğretmen adayları memnuniyetlerinin nedenlerini; yöntemin öğretmen adaylarını farklı bakış açılarına veya karşıt görüşlere değer vermeye teşvik ettiği, konuların daha kapsamlı öğrenilmesini sağladığı, fikirlerini ifade etmek için uygun ortamları oluşturduğu, araştırma-sorgulama isteğini arttırdığı, etkili öğrenme ve derse aktif katılım sağlandığ şeklinde ifade etmişlerdir.

Öğretmen Adayı 41; 'Memnunum çünkü derse olan katılımımız artıyor. Daha aktif ders işliyoruz.'

Öğretmen Adayı 36; ' Memnunum. Bir bilgiye doğrudan ulaşmayı değil, araştırıp sorgulayarak ulaşmamı sağladı. Daha fazla bilgi sahibi olmama katkı sağladı.

Öğretmen Adayı 18; ' Memnunum. Nedeni daha akılda kalıcıdır. Etkili öğrenmeyi să̆lar.'

Öğretmen Adayı 3 ; 'Tartışma sırasında birden fazla görüşe açık oluyoruz.'

Öğretmen Adayı 4; 'Grup çalışması yaparak daha yeni ve çeşitliliği bol fikirler ortaya konuluyor.'

Öğretmen adaylarından sadece 1 tanesi memnun olmadığını belirtmiştir.

Öğretmen Adayı 20; ' Memnun değilim. Kanıtlara göre çalıştığımızda pratik düşünme işlemi ortadan kalklyor ve bireylere odaklı çalışıyoruz. Sadece verilen bilgiye dayalı işlem yapılabiliyor. Serbest bir biçimde düşünemiyoruz.'

4) Argümantasyon tabanlı öğrenme yaklaşımının etkililiğine;

a) İnanıyor musunuz? Nedenlerini belirtiniz.

b) İnanmiyor musunuz? Nedenlerini belirtiniz.

Öğretmen adaylarına argümantasyon tabanlı öğrenme yaklaşımının etkililiğine inanıp inanmadıkları sorulmuş ve Öğretmen adaylarının tamamı yöntemin etkililiğine inandıklarını belirtmişlerdir. Öğretmen adayları yöntemin etkililiğine inanma nedenlerini kalıcı ve anlamlı öğrenme sağladığı, kendini ifade etme becerisini geliştirdiği ve farklı görüşlere değer verme yetisi kazandırdığı şeklinde ifade etmişleridir. Bazı görüşler aşağıda sunulmuştur.

Öğretmen Adayı 45; 'Karşı görüşlere karşı saygılı ve karşı görüşü benimseme becerilerini geliştirir.'

Öğretmen Adayı 7; 'İnanıyorum, bu sayede öğrencilerin kazandıkları bilgileri daha kalıci oluyor.

Öğretmen Adayı 14; 'Inanıyorum. Çünkü öğrenciye daha anlamlı öğrenme să̆lar.'

Öğretmen Adayı 16; 'Inanıyorum. Çünkü bildiğimiz konular bile olsa farklı yollardan ve bakış açısından tartışmamızı sağlar.'

Öğretmen Adayı 23; 'Ínanıyorum, çünkü ögrencilerin akıl yürütme becerisini arttırır. Kalıcı ögrenme să̆lar. Konuşma becerileri kazandırır.'

5) Ders sürecinde gerçekleştirilen bu uygulamadan sonra ileride öğretmenlik yaptığınız öğretim kurumlarında derslerinizi argümantasyon tabanlı öğrenme yaklaşımına göre etkinlikler kullanarak işlemeyi düşünür müsünüz? Nedenlerini belirtiniz. 
Öğretmen adaylarına öğretmenlik yaptığınız öğretim kurumlarında derslerinizi argümantasyon tabanlı öğrenme yaklaşımına göre etkinlikler kullanarak işlemeyi düşünüp düşünmedikleri sorulduğunda 47 öğretmen adayından 39 tanesi bu yöntemi kullanmayı düşündüklerini ifade etmiştir. Öğretmen adayları yöntemi kullanma nedenlerini araştıran, sorgulayan, kendini ifade edebilen, tartışan öğrenciler yetiştirmek istediklerini belirtmişlerdir. Ayrıca yöntemin, öğrenciler arasında etkili iletişimi gerçekleştirerek derse katılımı arttıracağını, kalıcı ve anlamlı öğrenmeler oluşturduğunu, öğrencilerde neden sonuç ilişkisi kurdurarak, akıl yürütme ve kanıt kullanımı ile öğrenmeyi kolaylaştırdığını ifade etmişlerdir. Öğretmen adaylarının bu konuda ifade ettikleri bazı görüşler aşağıda verilmiştir.

Öğretmen Adayı 15; 'Evet. Çünkü hem öğrenciler arasında iletişim sağlanır. Hem de arkadaşlarıyla tartışırken anlamlı bir öğrenme oluşur.'

Öğretmen Adayl 24; ' Düşünürüm. Doğru yapıldı̆̆ sürece bu etkinliklerin ögrencilerin sorgulama, tahmin etme, akl yürütme becerileri gelişir. Bu sayede daha etkili ve kalıcı bir öğrenme süreci olur.'

Öğretmen Adayı 6; 'Düşünürüm çünkü: argüman oluşturabilen birey hayatın her anında problem hakkında neden-sonuç ilişkisi kurabildiği için problemleri çözmekte daha rahat olurlar. Dinleme ve konuşma yetenekleri gelişmiş olur. Bir konuyu savunurken destekleyici sunma ve çürütücü kullanma yeteneğine sahip oldukları için kendilerini daha rahat ifade ederler.'

Öğretmen Adayı 36; ' Evet düşünürüm. Çünkü fen okuryazart öğrenciler yetiştirebilmek için araştırmacı, sorgulayıcı, bilgiyi doğrudan kabul etmeyen ögrenciler yetiştirmemiz gerekir.'

Öğretmen Adayı 34; 'Evet düşünürüm. Çünkü ögrrencide araştırma, kendini ifade etme, düşünme becerileri gelişir.'

Öğretmen adaylarından 4 tanesi argümantasyon tabanlı öğrenme yaklaşımını öğretmenlik yaptıkları öğretim kurumlarında kullanmayacaklarını belirtmiştir. Öğretmen adayları yöntemi kullanmama nedenlerini yöntemin fazla zaman alması ve görsel olmaması şeklinde ifade etmişlerdir. Bazı görüşler şöyledir:

Öğretmen Adayı 31; 'Hayır çünkü argümantasyon fazla zaman alıyor. O yüzden daha kolay ve çabuk öğrenilmesini sağlayan yöntemler bulmaya çalışırım.'

Öğretmen Adayı 17; 'Hayır. Çünkü artık teknolojik bir devirdeyiz. Daha çok görsel şeyler kullanmayı tercih ederim. Argümantasyon fazla zaman altyor ve bilginin daha geç ögrenilmesini sağllyor. O yüzden daha az zaman alan ve daha kolay ögrenmeyi sağlayan yöntemler kullanırım.'

Öğretmen Adayı 18; 'Hayır çünkü bilgiyi daha geç sürede öğreniyoruz.'

Öğretmen Adayı 16; ' Hayır çünkü argümantasyon fazla zaman alıyor, O yüzden daha kolay ve çabuk öğrenilmesini sağlayan yöntemler bulmaya çalışırım.'

Öğretmen adaylarından 2 tanesi argümantasyon tabanlı öğrenme yaklaşımını öğretmenlik yaptıkları öğretim kurumlarında sınıf ve öğrenci durumları uygun olduğu durumlarda kullanacaklarını belirtmişlerdir.

Öğretmen Adayı 7; 'Bulunduğum okulda ĕger ögrenim seviyeleri argümantasyon tabanlı ögrenmeye uygunsa veya yapabileceklerine inaniyorsam uygularım'

Öğretmen Adayı 44; 'Bu sınıfin durumuna bağlı uygun ortam olursa kullanırım.' 
Öğretmen adaylarından 2 tanesi argümantasyon tabanlı ögrenme yaklaşımını ögretmenlik yaptıkları öğretim kurumlarında sürekli değil ara ara kullanacaklarını belirtti.

Öğretmen Adayı 10; 'Düşünebilirim ama tüm etkinliklerde değil tabi. Uygun olabilecek etkinlikler ile yapmayı düşünürüm.'

Öğretmen Adayı 20; 'Tabi ara ara bu yöntemi kullanabilirim. Fakat bu yöntem biraz sıkıcı ve teoriktir. Ara ara kullanmakta fayda olacağını düşünüyorum.’

\section{SONUÇ VE TARTIŞMA}

Araştırma fen bilgisi öğretmen adaylarının argümantasyon tabanlı öğrenme yaklaşımına yönelik görüşlerini belirlemek amacıyla gerçekleştirilmiştir. Araştırmadan elde edilen veriler analiz edildiğinde katılımcı grupta yer alan öğretmen adayları argümantasyon tabanlı öğrenme yaklaşımının fen okuryazarlığı ve bilimsel okur yazarlığı geliştirmesi, akıl yürütme, karar verme, eleştirel düşünme, problem çözme becerilerini kazandırması, bireylerde etkili ve kalıcı öğrenmeler gerçekleştirmesi, grup çalışmalarında ve sınıf içinde sosyal etkileşimi sağlaması ve bireylere bilimsel bilginin oluşum sürecini bizzat yaşatması gibi özellikleri yöntemin avantajı olarak ifade etmişlerdir. Çalışmanın katılımcı grubunu oluşturan öğretmen adaylarından neredeyse hepsi derslerin argümantasyon tabanlı öğrenme yaklaşımına dayalı etkinliklerle işlenmesinden memnun olduklarını; bu yöntemin derse katılımı arttırdığını ve konuların daha kapsamlı olarak öğrenilmesine imkan sağladığını düşünmektedirler. Öğretmen adayları argümantasyon tabanlı öğrenme yaklaşımının kalıcı ve anlamlı öğrenmeler oluşturduğu, kendini ifade etme becerisini geliştirdiği ve farklı görüşleri dinlemeye teşvik ettiğini, bu nedenle etkili bir yöntem olduğunu belirtmişlerdir. Ayrıca öğretmen adaylarının büyük çoğunluğu yöntemin araştırmayı, sorgulamayı seven, bilgiyi doğrudan ezberlemeyip bilgiye kendi ulaşmaya çalışan bireylerin yetiştirilmesinde katkısı olacağını düşünerek ileride öğretmenlik yapacakları öğretim kurumlarında derslerini argümantasyon tabanlı öğrenme yaklaşımına dayalı etkinlikler ile işlemeyi düşündüklerini belirtmektedirler.

Alan yazındaki çalışmalara bakıldığında Yıldırır ve Nakiboğlu (2014)'nun kimya öğretmen ve öğretmen adaylarının derslerinde kullandıkları argümantasyon sürecinin belirlenmesi için 4 kimya öğretmeni ve 4 kimya öğretmen adayı ile yaptıkları çalışmada öğretmen adaylarının ve öğretmenlerin çoğunluğunun öğrencileri tartışmaya ve farklı görüşlere, bakış açılarına değer vermeye, dinlemeye teşvik ettiklerini belirlemiştir. Yine yukarıdaki çalışmanın bulgularına paralel olarak Tümay ve Köseoğlu (2010)'nun kimya öğretmen adaylarının argümantasyon odaklı öğretim konusunda anlayışlarının geliştirilmesi amacıyla 23 öğretmen adayı ile yürütülen çalışmanın sonucunda; öğretmen adayları argümantasyon odaklı öğretimin öğrencilerin derse aktif katılımını sağladığı, anlamlı öğrenmeler oluşturduğunu, düşünme ve sorgulama becerilerini geliştirdiğini ifade etmişlerdir.

Yine alan yazına bakıldığında farklı öğrenim seviyesindeki öğrenciler ile yapılan çalışmalarda, argümantasyon tabanlı öğrenme yaklaşımının derslerde kullanılması veya çeşitli etkinlikler ile ders kapsamına dahil edilmesi sonucunda öğrencilerin; derse katılımının arttı̆̆1, kalıcı öğrenmeler gerçekleştiği, ders kapsamında işlenen konuların daha detaylı öğrenildiği ve öğrencilere araştırma-sorgulama, problem çözme, düşünme becerisi kazandırdığı tespit edilmiştir (Kabataş Memiş, 2014; Günel, Kıngır ve Geban, 2012; Üstünkaya ve Savran Gencer, 2012).

$\mathrm{Bu}$ araştırmanın bulgularına göre öğretmen adayları argümantasyon tabanlı yaklaşımın olumlu yönlerinin yanı sıra dezavantajları olduğunu da belirtmişlerdir. Öğretmen adaylarına göre argümantasyon tabanlı yaklaşıma göre hazırlanan etkinliklerin olumsuz yanı fazla zaman alması, araştırma imkanları kısıtlı olduğu zaman ve kalabalık sınıflarda 
uygulamanın zor olmasıdır. Ayrıca öğretmen adayları bu yaklaşımın bireysel farklılıkları gözetmediği, çekingen veya içine kapanık öğrenciler için zor olacağını ve grup çalışmaları sırasında grup içi uyumsuzlukların veya sorunların yaşanabileceğini düşünmektedirler. $\mathrm{Bu}$ nedenle az sayıda öğretmen adayı mevcut durumdaki derslerin bu etkinlikler ile işlenmesinden memnun olmadıklarını ve ileride öğretmenlik yapacakları öğretim kurumlarında derslerini argümantasyon tabanlı öğrenme yaklaşımına göre hazırlanmış etkinlik kağıtları ile işlemeyeceklerini belirtmişlerdir. Bu durum öğretmen adaylarının argümantasyon tabanlı öğrenme yaklaşımı ile ilgili kapsamlı bilgiye sahip olmadıkları veya alan bilgilerinin yetersiz olması ile açıklanabilir. Öğretmen adaylarının grup çalışmalarında tartışma veya karşıt görüş dinlerken zorluk yaşamaları ve etkinlik kağıtlarını doldururken ders esnasında zaman sorunu yaşamaları tartışma yönetimi konusunda tecrübesiz olmaları ve argümantasyon tabanlı öğrenme yaklaşımına göre hazırlanan ders etkinliklerine alışık olmadıkları öğretim kurumlarında genellikle düz anlatım yapıldığı için yöntemin uygulama sürecine yeterince hakim olmadıkları için zaman alması ile açıklanabilir.

Argümantasyon tabanlı öğrenme yaklaşımı ile ilgili yapılan çalışmalar incelendiğinde bu yaklaşımın uygulanmasında ortaya çıkan sorunları tespit eden çalışmalarda vardır. Yapılan araştırmalar argümantasyon tabanlı öğrenme yaklaşımının öğretim ortamlarında uygulandığı esnada öğrencilere bilimsel düşünme, fikirlerini rahatça ifade etme gibi süreçlerde yeterince firsat verilmediği, tespit etmiştir. Araştırmalarda argümantasyon tabanlı öğrenme yaklaşımının sınıf içi uygulamaları için gerekli olan öğrenme ortamlarının oluşmadı̆̆ı, öğrencilerin kendi aralarında, grup içinde argümantasyon tabanlı yaklaşımın verimli şekilde uygulanması için gerekli olan iletişim becerilerini kazanamadığı bu sebepten dolayı da ne kendi fikirlerini ne de grup içindeki diğer arkadaşlarının fikirlerini etkili şekilde değerlendiremediği ortaya konmuştur (Erduran \& Jimenez - Aleixandre, 2007; Driver, Newton \& Osborne, 2000).

Argümantasyon tabanlı öğrenme yaklaşımının öğrencilerde ve öğretmen adayları üzerinde birçok olumlu etkisi olduğu görülmektedir. Düşünen, sorgulayan, bilgiyi olduğu gibi kabul etmeyen bireyler yetiştirmek fen eğitiminin en önemli amacıdır. Argümantasyon tabanlı öğrenme yaklaşımı da bu amaca hizmet eden yöntemlerden biridir.

Öğrencilerin derse olan tutumlarını olumlu yönde arttırmak, anlamlı ve kalıcı öğrenmeler sağlamak ve birbirlerini dinleyen ve birbirine karşı hoşgörülü yaklaşan bireyler olmaları için Fen derslerinde argümantasyon tabanlı öğrenmeye yönelik tekniklerin kullanılması önerilmektedir. Ayrıca argümantasyonun derslerde uygulanması sırasında argümantasyonun bileşenlerini öğrencilerin kavramaları ve öğrencilerin birbirine karşı hoşgörüyü öğrenmeleri zaman almaktadır. Bu nedenle sadece öğretmen adaylarının değil ilköğretimden itibaren başlayarak tüm bireyler için derslerde argümantasyonun kullanılmasının argümantasyona yönelik olumsuz görüşleri azaltacağı düşünülebilir.

\section{KAYNAKÇA}

Aktamış, H. ve Hiğde, E. (2015). Fen eğitiminde kullanılan argümantasyon modellerinin değerlendirilmesi. Mehmet Akif Ersoy Üniversitesi Ĕ̆itim Fakültesi Dergisi, 35, 136 172.

Aldağ, H. (2005). Düşünme aracı olarak metinsel ve metinsel-grafiksel tartışma yazılımının tartışma becerilerinin geliştirilmesine etkisi. Yayınlanmamış Doktora Tezi, Çukurova Üniversitesi, SBE, Adana.

Aydın, Ö. ve Kaptan, F. (2014). Fen-teknoloji öğretmen adaylarının eğitiminde argümantasyonun biliş üstü ve mantıksal düşünme becerilerine etkisi ve 
argümantasyona ilişkin görüşleri. Eğitim Bilimleri Araştırmaları Dergisi, 4(2), 163 188.

Aymen Peker, E., Apaydın, Z. ve Taş, E. (2012). Isı yalıtımını argümantasyonla anlama: İlköğretim 6. sınıf öğrencileriyle durum çalışması. Dicle Üniversitesi Sosyal Bilimler Enstitüsü Dergisi, 4(8), 79-100.

Ceylan, K. E. (2012). İlköğretim 5. sınıf öğrencilerine dünya ve evren öğrenme alanında bilimsel tartışma (argumantasyon) odaklı yöntem ile öğretimi. Yüksek Lisans Tezi. Gazi Üniversitesi. Ankara.

Driver, R., Newton, P. \& Osborne, J. (2000). Establishing the norms of scientific argumentation in classrooms. Science Education, 84(3), 287-312.

Eemeren, V. \& Frans, H. (1996). Fundamentals of argumentation theory. LEA.

Erduran, S., Simon, S. \& Osborne, J. (2004). Tapping into argumentation: Developments in the application of Toulmin's argument pattern for studying science discourse. Science Education, 88(6), 915-933.

Günel, M., Kıngır, S. ve Geban. Ö. (2012). Argümantasyon Tabanlı Bilim Öğrenme (ATBÖ) Yaklaşımının kullanıldığı sınıflarda Argümantasyon ve soru yapılarının incelenmesi. Ĕ̈itim ve Bilim, 37(174), 316-330.

Jiménez-Aleixandre, M. P., Bugallo Rodriguez, A. \& Duschl, R. A. (2000). "Doing the lesson" or "doing science": argument in high school genetics. Science Education, 84(6), 757-792.

Jiménez-Aleixandre, MP. \& Erduran, S. (2007). Argumentation in science education: An overview. Argumentation in Science Education, 35, 3-27.

Kabataş Memiş, E. (2014). İlköğretim öğrencilerinin argümantasyon tabanlı bilim öğrenme yaklaşımı uygulamalarına ilişkin görüşleri. Kastamonu Üniversitesi Kastamonu Ĕ̆itim Dergisi, 22(2), 401-418

Kaya, O.N. ve Kılıç, Z. (2008). Etkin Bir Fen Öğretimi İçin Tartışmacı Söylev. Ahi Evran Üniversitesi Kırşehir Ĕ̈itim Fakültesi Dergisi (KEFAD), 9(3), 89-100.

Keys, C.W., Hand, B., Prain, V. \& Collins, S. (1999). Using the science writing heuristic as a tool for learning from laboratory investigations in secondary science. Journal of Research in Science Teaching, 36(10), 1065-1084.

Kelly, G. J. \& Takao, A. (2002). Epistemic levels in argument: An analysis of university oceanography students' use of evidence in writing. Science Education, 86(3), 314-342.

Kıngır, S., Geban, Ö. ve Günel, M. (2010). Argümantasyon tabanlı bilim öğrenme (atbö) yaklaşımının 9. sınıf öğrencilerinin kimya kavramlarını öğrenmelerine etkisi. $I X$. Ulusal Fen Bilimleri ve Matematik Eğitimi Kongresi Bildiriler Kitabı, İzmir.

Köseoğlu, F., Tümay, H. ve Budak, E. (2008). Bilimin doğası hakkında paradigma değişimleri ve öğretimi ile ilgili yeni anlayışlar. Gazi Eğitim Fakültesi Dergisi, 28(2), 221-237.

Kuhn, D. (2009). Teaching And Learning Science as Argument.

Lawson, T. (2003). Reorienting economics. Psychology Press. 
McNeill, K. L., Lizotte, D. J., Krajcik, J. \& Marx, R. W. (2006). Supporting students' construction of scientific explanations by fading scaffolds in instructional materials. The Journal of the Learning Sciences, 15(2), 153-191.

Naylor, S., Downing, B. \& Keogh, B. (2001). An empirical study of argumentation in primary science, using Concept Cartoons as the stimulus. In 3rd Conference of the European Science Education Research Association Conference, Thessaloniki, Greece.

Osborne, J., Erduran, S., \& Simon, S. (2004). Enhancing the quality of argument in school science. Journal of Research in Science Teaching, 41(10), 994-1020.

Sandoval, W. A. (2003). Conceptual and epistemic aspects of students' scientific explanations. The Journal of the Learning Sciences, 12(1), 5-51.

Schwarz, B. B., Neuman, Y., Gil, J. \& Ilya, M. (2003). Construction of collective and individual knowledge in argumentative activity. The Journal of the Learning Sciences, 12(2), 219-256.

Şimşek, H. ve Yıldırım, A. (2011). Sosyal bilimlerde nitel araştırma yöntemleri. Ankara: Seçkin Yayıncılık.

Toulmin, S. (1958). The Uses of Argument Cambridge University Press.Cambridge, UK.

Tümay, H. ve Köseoğlu, F. (2011). Kimya öğretmen adaylarının argümantasyon odaklı öğretim konusunda anlayışlarının geliştirilmesi. Türk Fen Eğitimi Dergisi, 8(3), 105 119.

Ulu, C. ve Bayram, H. (2015). Argümantasyon tabanlı bilim öğrenme yaklaşımına dayalı laboratuar etkinliklerinin 7. Sınıf öğrencilerinin kavram öğrenmelerine etkisi: Yaşamımızdaki elektrik ünitesi. Pamukkale Üniversitesi Eğitim Fakültesi Dergisi,37,63-77.

Üstünkaya, I. ve Savran Gencer, A. (2012). İlköğretim 6. Sinıf seviyesinde bilimsel tartışma(argumentation) odakl etkinliklerle dolaşım sistemi konusunun öğretiminin akademik başarıya etkisi. X. Ulusal Fen ve Matematik Eğitimi Kongresinde Sunulan Bildiri. Niğde Üniversitesi.

Yeşildağ-Hasançebi, F. ve Günel M. (2013). Effects of argumentation based inquiry approach on disadvantaged students' science achivement. Elementary Education Online, 12(4), 1056-1073.

Yıldırır, H. E. ve Nakiboğlu, C. (2014). Kimya öğretmen ve öğretmen adaylarının derslerinde kullandıkları argümantasyon süreçlerinin incelenmesi. Abant İzzet Baysal Üniversitesi Ĕ̈itim Fakültesi Dergisi, 14(2), 124-154.

Zengin, F. K., Kırılmazkaya, G. ve Keçeci, G. (2011). Elementary students use of smart board the effect of achievement and attitude in science and technology course. In 5th International Computer \& Instructional Technologies Symposium, 22-24.

Zengin, F.K., Keçeci, G. ve Kırılmazkaya, G. (2012). İlköğretim öğrencilerinin nükleer enerji sosyo-bilimsel konusunu online argümantasyon yöntemi ile öğrenmesi. e-Journal of New World Sciences Academy, 7(2), 647-654.

Zohar, A. \& Nemet, F. (2002). Fostering students' knowledge and argumentation skills through dilemmas in human genetics. Journal of Research in Science Teaching, 39(1), $35-62$. 